\title{
A note on the tonka bean and William Forsyth junior's 'A botanical nomenclator' (1794)
}

\author{
D.J. Mabberley ${ }^{1}$
}

Key words

\section{Dipteryx}

Lamarck

Psychotria

Räuschel

tonka bean

William Forsyth junior

\begin{abstract}
The 70 new combinations made in Forsyth's 'A botanical nomenclator' (1794) include ten names in current use, but hitherto attributed to later authors, notable being that of the economically significant Dipteryx odorata (tonka bean), Leguminosae. Of Forsyth's 26 nomina nova, Psychotria caerulea Forsyth f. (1794) is an older name for the homotypic $P$. amplifolia Raeusch. (1797), Rubiaceae. Also pointed out are four names in current use to be cited as of Lamarck and one as of Räuschel, rather than later authors. All other novelties, none apparently affecting current nomenclature, have been passed to IPNI editors.
\end{abstract}

Published on 6 June 2017

\section{THE TONKA BEAN}

Tonka beans are used in European cooking and scents, the basis being the coumarin (from the French word 'coumarine', derived from the Tupi (a lingua franca in 18th-century tropical America) name kumaru for tonka, a Galibi (Carib) name), from which anticoagulant drugs like warfarin were originally derived. In 1954 tonka beans were banned as a food ingredient in the United States, and since then in tobacco too, though they are still an adulterant in Mexican vanilla. Moreover, they are important as flavouring in certain European liqueurs, notably (the Dutch) Van Wees Tonkabonen Esprit, (the German) Michelberger Forest Kräuterlikör and (the French) Pastis Henri Bardouin (Stewart 2013: 197).

In preparing my lecture courses in Economic Botany at Leiden University, I recently became aware that the currently accepted name for tonka bean, Dipteryx odorata (Leguminosae), was first coined by William Forsyth junior in 1794, some years before the widely quoted attribution, to Willdenow, as set out below.

\section{WILLIAM FORSYTH AND HIS 'A BOTANICAL NOMENCLATOR'}

William Forsyth (?1772-1835) was a bibliophile seedsman, the eldest son of one of the founders of the Horticultural Society and gardener to England's George III at Kensington and St James's in London (Henrey 2 (1975) 353), William Forsyth (1737-1804) after whom Forsythia Vahl (Oleaceae) is named. Much confused with his father in the secondary literature, William Forsyth junior was in partnership with James Gordon (c. 1708-1780; commemorated in Gordonia J.Ellis, Theaceae), seedsman of Fenchurch Street, with a nursery at Mile end, later Bow, London.

According to Loudon (1835), Forsyth "was chiefly remarkable for having one of the best horticultural libraries that was perhaps ever formed, and for his bibliographical knowledge, more espe-

\footnotetext{
Wadham College, University of Oxford, United Kingdom; Universiteit Leiden and Naturalis Biodiversity Center, Leiden, The Netherlands; Macquarie University and National Herbarium of New South Wales, Sydney, Australia; e-mail: david.mabberley@rbgsyd.nsw.gov.au.
}

cially in botanical and horticultural literature". Forsyth prepared a number of publications including an Arboretum britannicum, but his only published work was his 'A botanical nomenclator; containing a systematical arrangement of the classes, orders, genera, and species of plants, as described in the new edition of Linnaeus's Systemae Naturae by Dr. Gmelin of Gottingen' in which the name Dipteryx odorata was published.

Besides there being copies in a number of prominent libraries including Harvard University Herbaria, Natural History Museum London and Royal Botanic Gardens Kew, Forsyth's book (Henrey no. 719), has also been available in facsimile form since 2009 (Kessinger Publishing, USA), besides having been digitized by both Hathi Trust and Biodiversity Heritage Library. It seems extraordinary that Forsyth's meticulous work has hitherto been disregarded and that his new names are not listed in IPNI (IPNI 2017, accessed 4 May 2017), which is the benchmark used in this note (all novelties listed in this note have been passed to the IPNI editors).

With a Preface dated April 1794, 'A botanical nomenclator' in effect pre-empted many of the new combinations proposed by Willdenow and others, as well as some of the rather dubious ones of Räuschel (1797; see Howard (1975)). Forsyth's book is numbered as columns, two per page, so that the correct citation of the name for the tonka bean is therefore:

Dipteryx odorata (Aubl.) Forsyth f. (1794) col. 391; Willd. 3 (1802) 910, isonym as 'Dipterix' - Leguminosae (Central America and northern South America)

Basionym. Coumaruna odorata Aubl. 2 (1775) 740.

\section{FORSYTH'S OTHER NEW COMBINATIONS}

Whilst preparing a new edition (2017) of 'Mabberley's Plantbook', I checked whether any of the rest of the 70 validly published but previously unlisted new combinations made by Forsyth in his book antedated those generally accepted for other currently used names. There are indeed nine more, some of which names are used in the new edition of 'Mabberley's Plantbook' while all are made somewhat securer by these findings (see especially Justicia ovata below), this note thus providing the evidence for the attributions accepted in my new edition: 
Allophylus cobbe (L.) Forsyth f. (1794) col. 226; Raeusch. (1797) 108 , isonym - Sapindaceae ((A. cobbe s.I.) Old World tropics)

Basionym. Rhus cobbe L. (1753) 267.

Note - See Howard (1975). According to Werner Greuter (pers. comm. 22 April 2017), the title of Räuschel's book is to be considered adequate to constitute an indirect reference to Linnaeus's basionym, validating this isonym, and many others, in his book. The remaining valid names have their basis in other works cited in his preface. Nonetheless, there are several names in his text with direct references to basionyms, e.g., of names in current use, Croton cascarilloides Raeusch. and Potentilla erecta (L.) Raeusch., though some in this category have been inexplicably overlooked. These include the following name in current use:

Pterospermum suberifolium (L.) Raeusch. (1797) 185; Willd. 3 (1800) 728, isonym - Malvaceae (India, Sri Lanka)

Basionym. Pentapetes suberifolia L. 2 (1753) 698.

Crudia aromatica (Aubl.) Forsyth f. (1794) col. 247; Willd. 2 (1799) 540, isonym - Leguminosae (northern South America)

Basionym. Touchiroa aromatica Aubl. 1 (1775) 385.

Crudia spicata (Aubl.) Forsyth f. (1794) col. 247; Willd. 2 (1799) 539, isonym - Leguminosae (northern South America)

Basionym. Apalatoa spicata Aubl. 1 (1775) 383.

Justicia ovata (Walter) Forsyth $\mathrm{f}$. (1794) col. 13; Lindau in Urban (1900) 237, isonym - Acanthaceae (E and SE United States)

Basionym. Dianthera ovata Walter (1788) 63.

Note - This removes the threat from any publication that may be found validating 'J. ovata E. Meyer', first published as a nomen nudum for an African plant (Isoglossa ovata (Nees) Lindau) in 1843.

Manettia alba (Aubl.) Forsyth f. (1794) col. 104; Wernham (1918) 29, isonym - Rubiaceae (French Guiana)

Basionym. Nacibea alba Aubl. 1 (1775) 98.

Manettia coccinea (Aubl.) Forsyth f. (1794) col. 104; Willd. 1 (1798) 625, isonym - Rubiaceae (Central and South America)

Basionym. Nacibea coccinea Aubl. 1 (1775) 96.

Psychotria lutea (Aubl.) Forsyth f. (1794) col. 132; Willd. 1 (1799) 971, isonym - Rubiaceae (northern South America)

Basionym. Nonatelia lutea Aubl. 1 (1775) 190.

Psychotria paniculata (Aubl.) Forsyth f. (1794) col. 132; Raeusch. (1797) 56, isonym (nomen nudum?) - Rubiaceae (northern South America)

Basionym. Nonatelia paniculata Aubl. 1 (1775) 184.

Note - See Howard (1975), as Aublet is not one of the authors cited by Räuschel in his preface.

Trichilia mucronata (Cav.) Forsyth f. (1794) col. 249; Harms (1940) 116, 177; isonym - Meliaceae (Madagascar)

Basionym. Portesia mucronata Cav. (1789) 370.

\section{FORSYTH'S NOMINA NOVA}

In his 'Nomenclator', Forsyth also proposed over 25 nomina nova, almost all of them superfluous (illegitimate) names, several also to be found as isonyms in the later work of Willdenow. Only one has any nomenclatural effect, being the currently correct name for a Neotropical Rubiacea:

Psychotria caerulea Forsyth f. (1794) col. 132 (non P. caerulea Ruiz \& Pav. (1799, nom. illeg. = P. brachiata Sw.) - Rubiaceae (northern South America)

Basionym. Nonatelia violacea Aubl. 1 (1775) 188 (non P. violacea Aubl. = Geophila repens (L.) I.M.Johnst.).

Psychotria amplifolia Raeusch. (1797) 56, nom. illeg., superfl.

\section{UNLISTED LAMARCK, AND OTHER, NAMES CORRECTLY CITED BY FORSYTH}

Besides the principal source for Forsyth's work, Gmelin's 'Systema naturae per regna tria naturae' (1788-1793), another important book amongst the texts listed in Forsyth's Preface is Lamarck's 'Tableau encyclopédique et méthodique des trois règnes de la nature. Botanique'(1791-). Many dozens of new names taken from the books he cited in his preface were correctly recorded by the scholarly Forsyth, but inexplicably unlisted since. None of these appears to affect names in current use. On the other hand, it is worth pointing out that a number of other unlisted Lamarck 'Tableau' names were not cited by Forsyth, the only four in current use being:

Alchemilla capensis Lam. I, 1 (1792) 347; Thunb. 1 (1794) 31, isonym - Rosaceae (South Africa)

Cissus rotundifolia Lam. I, 1 (1792) 331, Vahl (1794) 18, isonym - Vitaceae (East Africa to Arabia)

Pimelea gnidia (J.R.Forst. \& G.Forst.) Lam. I, 1 (1791) 31; Willd. 1 (1797) 50, isonym - Thymelaeaceae (New Zealand)

Basionym. Banksia gnidia J.R.Forst. \& G.Forst. (1776) 8 [indirect reference].

Pimelea prostrata (J.R.Forst. \& G.Forst.) Lam. I, 1 (1791) 31; Willd. 1 (1797) 51, isonym - Thymelaeaceae (New Zealand) Basionym. Banksia prostrata J.R.Forst. \& G.Forst. (1776) 8.

Acknowledgment I am grateful to Peter Crossing (Sydney) for allowing me to examine his personal copy of Forsyth's book.

\section{REFERENCES}

Aublet JBCF. 1775. Histoire des plantes de la Guiane Françoise: rangées suivant la méthode sexuelle, avec plusieurs mémoires sur différens objects intéressans, relatifs à la culture \& au commerce de la Guiane Françoise, \& une notice des plantes de l'Isle-de-France. Four vols. London, Didot, Paris. Cavanilles AJ. 1789. Septima dissertatio botanica. Didot, Paris.

Forster JR, Forster G. 1776. Characteres generum plantarum, quas in itinere ad insulas maris Australis: collegerunt, descripserunt, delinearunt, annis 1772-1775. White etc., London.

Forsyth Jr W. 1794. A botanical nomenclator; containing a systematical arrangement of the classes, orders, genera, and species of plants, as described in the new edition of Linnæus's systema naturæ, by Dr. Gmelin, of Gottingen. To which are added, alphabetical indexes of the Latin and English names of the plants, together with the names of the countries of which they are natives; also the number of British species. Cadell etc., London. 
Gmelin JF. 1788-1793. Systema naturae per regna tria naturae: secundum classes, ordines, genera, species, cum characteribus, differentiis, synonymis, locis. Beer, Leipzig.

Harms H. 1940. Meliaceae. In: Engler A, Prantl K, Die natürlichen Pflanzenfamilien, ed. 2, 19b 1: 1-172. [1960 reprint:] Duncker \& Humblot, Berlin.

Henrey B. 1975. British botanical and horticultural literature before 1800 . Three volumes. Oxford University Press, London.

Howard RA. 1975. Gaultheria swartzii, nom. nov. and the combinations in Raeuschel's nomenclator. Journal of the Arnold Arboretum 56: 240-242.

IPNI. 2017. The International Plant Names Index. http://www.ipni.org.

Lamarck J-BPAM[, Poiret JLM]. 1791-1823. Tableau encyclopédique et méthodique des trois règnes de la nature. Botanique. Three tomes (six volumes). Panckoucke, Paris.

Linnaeus C. 1753. Species plantarum: exhibentes plantas rite cognitas, ad genera relatas, cum differentiis specificis, nominibus trivialibus, synonymis selectis, locis natalibus, secundum systema sexuale digestas. Two volumes. Salvius, Stockholm

Loudon JC. 1835. ART. VI. Obituary. Gardener's Magazine and Register of Rural and Domestic Improvement 11: 496

Mabberley DJ. 2017. Mabberley's Plant-book. Fourth edition. Cambridge University Press, Cambridge.

Räuschel EA. 1797. Nomenclator botanicus omnes plantas ab illustr. Carolo a Linné descriptas aliisque botanicis temporis recentioris detectas enumerans, ed. 3. Feind, Leipzig.
Stewart A. 2013. The drunken botanist. The plants that create the world's greatest drinks. Algonquin, Chapel Hill, North Carolina.

Thunberg CP. 1794. Prodromus plantarum capensium, quas in Promontorio Bonae Spei Africes, annis 1772-1775, collegit Carol. Peter. Thunberg. Vol. 1. Upsala.

Urban I. 1900. Symbolae Antillanae, seu, fundamenta florae Indiae Occidentalis, volume 2. Borntraeger, Leipzig; Klincksieck, Paris; Williams \& Norgate, London.

Vahl M. 1794. Symbolae botanicae, sive plantarum, tam earum, quas in itinere, imprimis orientali, volume 3. Copenhagen.

Walter T. 1788. Flora caroliniana: secundum systema vegetabilium perillustris Linnaei digesta; characteres essentiales naturalesve et differentias veras exhibens; cum emendationibus numerosis: descriptionum antea evulgatarum: adumbrationes stirpium plus mille continens: necnon, generibus novis non paucis, speciebus plurimis novisq. ornata. Fraser, London.

Wernham HF. 1918 [Sept.]. The genus Manettia. Tropical American Rubiaceae - X. Journal of Botany, British and Foreign (London) 56 suppl.: 1-32 1919 [Mar.] ibid., 57 suppl.: 33-44.

Willdenow CL. 1797-1825. Species plantarum: exhibentes plantas rite cognitas ad genera relatas, cum differentiis specificis, nominibus trivialibus, synonymis selectis, locis natalibus, secundum systema sexuale digestas. Ed. 4. Post Reichardianem quinta adjectis vegetabilibus hucusque cognitis curante Carolo Ludovico Willdenow. Six volumes. Nauk, Berlin. 